INTERNATIONAL JOURNAL OF ENGINEERING, SCIENCE AND TECHNOLOGY

www.ijest-ng.com

www.ajol.info/index.php/ijest

(C) 2017 MultiCraft Limited. All rights reserved

\title{
Thermophysical characterization of the powder resulting from the solar drying of the Moringa oleifera leaves
}

\author{
Codjo Goudjinou ${ }^{1,2}$, Clément Ahouannou ${ }^{2 *}$, Gédéon Chaffa ${ }^{2}$, Mohamed M. Soumanou ${ }^{1}$ \\ ${ }^{1}$ Units of Research in Enzyme Engineering and Food (URGEA), Laboratory of Study and Applied Chemistry Research (LERCA), \\ Department of Food Technology Engineering, Polytechnic College of Abomey-Calavi, Abomey-Calavi University, BENIN. \\ ${ }^{2}$ Laboratory of Energetics and Applied Mechanics (LEMA), Polytechnic College of Abomey-Calavi, \\ Abomey-Calavi University, 01P.O.BOX 2009, Cotonou, BENIN \\ *Corresponding Author: e-mail: ahouannou_clem@yahoo.fr, Tel 00 (229) 2113534501 BP 2009, Cotonou, BÉNIN
}

\begin{abstract}
This paper presents the results of thermophysical characterization of the powder resulting from the solar drying of Moringa oleifera leaves. The desorption isotherms of the powder, are determined by the gravimetric static method. The models of B.E.T, Smith, Henderson, Iglesias and GAB are used for the smoothing of the experimental points. The Clausius-Clayperon and GibbsHelmholtz equation are used for the determination of thermodynamic properties. The isotherms obtained are with type II. The theoretical curves of $\mathrm{GAB}$ present a better similarity with the experimental curve at $55^{\circ} \mathrm{C}$. The monolayer moisture content $(\mathrm{Xm})$ is 6.32 and $7.24 \%$ at $30^{\circ} \mathrm{C} ; 5.13$ and $6.3 \%$ at $35^{\circ} \mathrm{C} ; 5.1$ and $5.9 \%$ at $45{ }^{\circ} \mathrm{C} ; 4.22$ and $4.66 \%$ at $55^{\circ} \mathrm{C}$ respectively for BET and $\mathrm{GAB}$ models. Isosteric and entropic heats are more important for low values of moisture content. The activation energy of desorption of the powder in the range of temperatures tested is $-10.1009539 \mathrm{~kJ} / \mathrm{mol}$. Isokinetic temperature (T $\beta$ ) and the mean harmonic temperature (Thm) are respectively $301.2435 \mathrm{~K}$ and $300.12342 \mathrm{~K}$ and the free energy ( G $\beta$ ) is $302.18 \mathrm{~J} / \mathrm{mol}$. The desorption process of the Powder is non-spontaneous and is done by controlled mechanisms enthalpic.
\end{abstract}

Keywords: Moringa oleifera, Thermophysical characterization, Desorption isotherm, Thermodynamic properties, Modelization

DOI: http://dx.doi.org/10.4314/ijest.v9i4.4

\section{Introduction}

Moringa oleifera is increasingly used as food supplement for the fight against protein energetics malnutrition and micronutrient deficiencies. Indeed, the principal form of use of this plant is the consumption of leaves in the form of powder (Goudjinou et al., 2016). The conservation in time of the latter requires knowledge of its thermophysical parameters. The temperature, the $\mathrm{pH}$ and water activity are recognized as the principal factors intervening in stability, during food preservation (Benhamou et al, 2010). The knowledge of the water activity in the matter is of a considerable interest in food technology. The typical form of an isotherm reflects how water is bound to product (Wolf et al, 1985). A moisture sorption isotherms represent the relationship of the equilibrium moisture content of a food product and the relative humidity at a particular temperature (Muzaffar and Kumar, 2016; Aguirre-Ldredd et al., 2017). In accordance with the fixed relative humidity, the product can adsorb or lose moisture with the surroundings, thus the phenomena of adsorption or desorption, respectively, can be present (Coronel et al., 2016). Water activity is widely used as a reference parameter in most applications of food processing and storage for a variety of reasons: it is a determinant for the growth of microorganisms; it is well related with most degradation reactions of a chemical, enzymatic, and physical nature; the "monolayer" derived from the water vapour sorption isotherm gives an indication of the optimum moisture content in dried foods. The sorption isotherms are essential properties in the analysis and design of various biological material processes such as preservation, drying, storing, packaging and mixing. It can be used to determine the net isosteric heat of sorption (Simo-Tagne et al., 2016) for selecting appropriate storage conditions and packing systems that optimize or maximize the mechanical stability of biological material. 
The knowledge of the relationship between the equilibrium moisture content, equilibrium relative humidity and temperature is very important in order to describe the effect of water activity on storage of foods (Aguirre-Ldredd et al., 2017).The knowledge and understanding of moisture sorption isotherms for food products is of great importance in design and optimisation of processing as for instance in drying, for assessing packaging problems, for modelling moisture changes which occur during drying, for predicting shelf life stability, for ingredient mixing predictions etc (Mahmoud et al., 2017). The study of moisture sorption is important to preserve the function of bioactive compounds constituent and maintain longer lifespan consumer. Thus, the sorption isotherm is an extremely valuable tool to characterize the powder, to determine the optimum storage conditions, for choosing a package and to determine the shelf life during storage (Taoufik et al., 2017). To better characterize the powder produced, besides the sorption curves, it would be interesting to determine the thermodynamic properties of this powder as a function of its water content. These are data necessary for the design of drying, of transformation and production of foodstuffs. The relation between the enthalpy and entropy is used to evaluate the physical and chemical phenomena which product the sorption reactions (Ngono Mbarga et al., 2017).Various mathematical models were proposed to describe the isothermal curves of water vapor sorption of the foodstuffs (Taoufik et al., 2017). These models, and in particular the simplest expressions (linear) of the water content according to the water activity are particularly useful in agribusiness (Erbas et al., 2005; Zhu et al., 2016). All these models, which they are a theoretical base or which they are empirical can help to understand the capacity of water adsorption by the product into monolayer or multilayer and sometimes to determine the adsorbent surface in the product. In this article we present the results of desorption isotherms of the Moringa oleifera leaf powder for four temperatures: $30,35,45$ and $55{ }^{\circ} \mathrm{C}$. In order to interpret the desorption curves obtained, some models described in the literature are used for the adjustment and modeling of experimental isotherms. Then, the thermodynamic functions calculated starting from these sorption isotherms, are evaluated in order to improve the interpretation of the experimental results. The thermodynamic functions concerned are the heat of sorption and the variations of enthalpy and entropy.

\section{Production of the Moringa oleifera leaf powder}

The production diagram (Figure 1) of the Moringa oleifera leaf powder (PFMo) follows three main steps consisting of simple unit operations of leaf health. Those are sorted, washed, wiped and dried. The convective drying of the leaves is done at $50{ }^{\circ} \mathrm{C}$ and with a draining air flow $\mathrm{Dv}=0.8 \mathrm{~m}^{3} / \mathrm{s}$ in an indirect solar drier whose prototype is represented on Figure 2. After drying, the leaves are ground and sieved. The powder thus obtained is immediately conditioned and then used for thermophysical characterization.

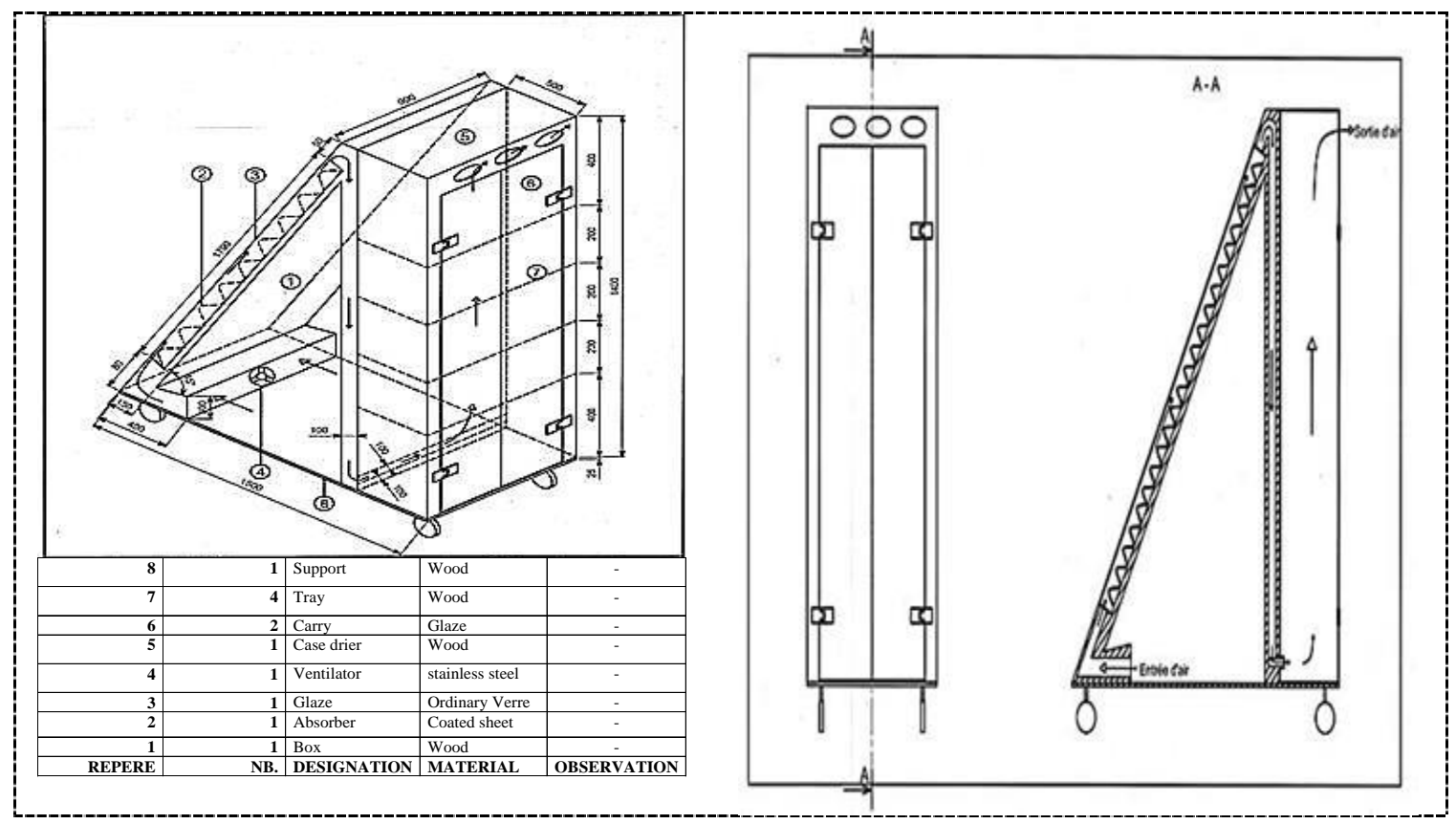

Figure1. Prototype of indirect solar drier realized (LEMA/EPAC/UAC) 


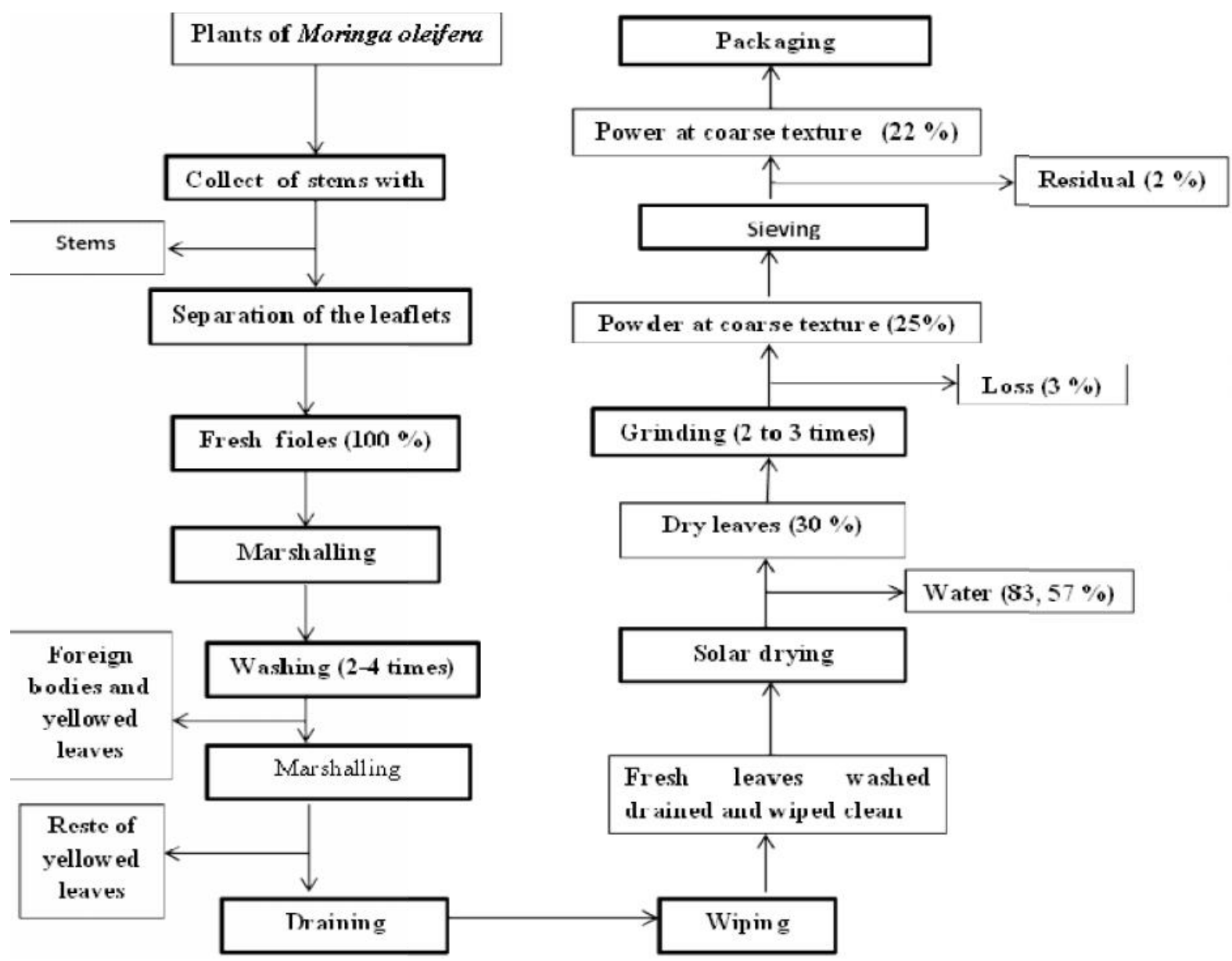

Figure2. Diagram of production of the Moringa oleifera leaf powder (PFMo)

\section{Determination of desorption isotherms}

The gravimetric static method was used for the determination of desorption isotherms of the powder. The experiment consists in putting the samples to be desorbed in isothermal hermetic bottles containing saturated salts solutions and maintained at temperature and relative humidity constants in a controlled drying oven (Wolf et al, 1985). The desorption experiments are carried out at $30^{\circ} \mathrm{C}$ (ambient temperature), $35^{\circ} \mathrm{C}, 45^{\circ} \mathrm{C}$ and $55^{\circ} \mathrm{C}$ and at nine values of relative humidity (Table 1). When the various equilibrium masses are obtained for the various desired climatic conditions, the samples tested are taken again then immediately placed in the drying oven of desiccation regulated with $103{ }^{\circ} \mathrm{C} \pm 2$. This operation allows to obtain the dry extracts of the studied samples, which undergo in this condition, the total loss free waters and bound that they contain (Ahouannou et al., 2010). The samples are regularly weighed and if at the end of 24 hours their masses do not vary any more, then the dry extract is obtained. Thus, the mass measured for each sample is regarded as the mass anhydrous $\left(\mathrm{M}_{\mathrm{s}}\right)$. From this parameter obtained, we defined the various equilibrium moisture contents of the samples.

The equilibrium moisture content of the product on dry basis is calculated by the following expression:

$$
X_{e q}(\%)=100 \times \frac{\left(M_{e q}-M_{s}\right)}{M_{s}}
$$

Xeq: equilibrium moisture content of the sample (\% bs); Me: equilibrium mass of the sample tested ( $\mathrm{g}) ; \mathrm{M}_{\mathrm{s}}$ : mass anhydrous of the sample tested (g). 
For a given temperature, the various couples values obtained (Hri, Xeqi) for $\mathrm{i}=1 . ., \mathrm{n} \in \mathrm{N}$, has allowed to plot experiments iso therms of desorption of the powder. Consequently, the equilibrium moisture content of the product can be expressed by the following relation:

$$
X_{e q}=f\left(a_{\mathrm{w}}\right)_{T_{s}}
$$

Where:

Ts, equilibrium temperature of the system in Kelvin, $\mathrm{a}_{\mathrm{w}}$ : water activity of the product, in decimal fraction, given by the relation:

$$
a_{w}=\frac{P_{V}}{P_{v s a t}}=\frac{H_{r}(\%)}{100}
$$

Where:

$\mathrm{Pv}$, vapor pressure at the surface of the product; Pvsat, vapor pressure saturation at the temperature of the system.

The relation between water activity, the temperature and the solutions saturated salt works prepared in distilled water are determined by equation (Labuza et al., 1985):

$$
\text { Ln aw }=\frac{\mathrm{K} 1}{\mathrm{~T}}-\mathrm{K} 2
$$

\begin{tabular}{|c|c|c|c|c|c|}
\hline \multirow[b]{2}{*}{ Sels } & \multirow[b]{2}{*}{$\operatorname{Ln} a_{w}=\frac{K_{1}}{T}-K_{2}$} & \multicolumn{4}{|c|}{$\mathbf{a}_{\mathbf{w}}$} \\
\hline & & $3^{\circ}{ }^{\circ} \mathrm{C}$ & $35^{\circ} \mathrm{C}$ & $45^{\circ} \mathrm{C}$ & $55^{\circ} \mathrm{C}$ \\
\hline $\mathrm{LiBr}$ & $\mathrm{Ln} \mathrm{a}_{\mathrm{w}}=(620.6358 \times 1 / \mathrm{T})-4.8327$ & 6.20 & 6.00 & 5.70 & 5.40 \\
\hline $\mathrm{KOH}$ & $\mathrm{Ln} \mathrm{a}_{\mathrm{w}}=(2094.4890 \times 1 / \mathrm{T})-9.4977$ & 7.20 & 6.70 & 5.90 & 5.60 \\
\hline $\mathrm{LiCl}$ & $\operatorname{Ln~}_{w}=(10.8233 \times 1 / T)-2.2193$ & 11.30 & 11.3 & 11.20 & 11.00 \\
\hline $\mathrm{MgCl} 2$ & $\operatorname{Ln} a_{w}=(151.0652 \times 1 / T)-1.6271$ & 32.40 & 32.10 & 31.10 & 29.9 \\
\hline $\mathrm{CoCl} 2$ & $\operatorname{Ln~}_{\mathrm{w}}=(982.7329 \times 1 / \mathrm{T})-5.0477$ & 61.8 & 58.60 & 52.60 & 48.00 \\
\hline KI & $\operatorname{Ln} a_{w}=(258.1545 \times 1 / T)-1.2388$ & 67.89 & 66.96 & 65.26 & 63.78 \\
\hline $\mathrm{NaCl}$ & $\operatorname{Ln} a_{w}=(23.1092 \times 1 / T)-0.3607$ & 75.1 & 74.90 & 74.50 & 74.40 \\
\hline $\mathrm{KCl}$ & $\operatorname{Ln} a_{w}=(157.0587 \times 1 / T)-0.6967$ & 83.6 & 83.00 & 81.70 & 80.7 \\
\hline $\mathrm{K}_{2} \mathrm{SO}_{4}$ & $\operatorname{Ln} a_{w}=(52.7544 \times 1 / T)-0.2046$ & 97.00 & 96.70 & 96.10 & 96.00 \\
\hline
\end{tabular}

Table 1. Standards values of water activity according to salts and the temperature

Source: (Labuza et al., 1985)

\section{Modelization isotherms}

The theoretical reproducibility of the desorption curves obtained experimentally was made following five (5) models described in the literature and commonly used for an optimal adjustment. It is:

- BET Model (1938)

The model B.E.T is most often applied to fruits and foods. This equation provides the value of the monolayer moisture content, which is an important parameter in the study of food deterioration. This model is valid until aw $=0.5$ only (Akoy et al., 2013). The B.E.T model is represented by the following equation: 


$$
\mathrm{X}_{\mathrm{eq}}=\frac{\mathrm{X}_{\mathrm{m}} \mathrm{Ca}_{\mathrm{w}}}{\left(1-\mathrm{a}_{\mathrm{w}}\right)\left(1+(\mathrm{C}-1) \mathrm{a}_{\mathrm{w}}\right)}
$$

Equation $\{$ (Eq. 5) $\}$ can be transformed into $\{($ Eq. 6) $\}$

$$
\begin{aligned}
& X_{\text {eq }}\left(1-a_{w}\right)\left[1+(C-1) a_{w}\right]=X_{m} C a_{w} \\
& \left(1-a_{w}\right)+\left(1-a_{w}\right)(C-1) a_{w}=\frac{X_{m} C a_{w}}{X_{e q}} \\
& \frac{\left(1-\mathrm{a}_{\mathrm{w}}\right)}{\mathrm{CX}_{\mathrm{m}}}+\frac{\left(1-\mathrm{a}_{\mathrm{w}}\right)(\mathrm{C}-1) \mathrm{a}_{\mathrm{w}}}{\mathrm{CX}_{\mathrm{m}}}=\frac{\mathrm{a}_{\mathrm{w}}}{\mathrm{X}_{\mathrm{eq}}} \\
& \frac{1}{\mathrm{CX}_{\mathrm{m}}}+\frac{(\mathrm{C}-1) \mathrm{a}_{\mathrm{w}}}{\mathrm{CX}_{\mathrm{m}}}=\frac{\mathrm{a}_{\mathrm{w}}}{\left(1-\mathrm{a}_{\mathrm{w}}\right) \mathrm{X}_{\mathrm{eq}}} \\
& \frac{\mathrm{a}_{\mathrm{w}}}{\left(1-\mathrm{a}_{\mathrm{w}}\right) \mathrm{X}_{\mathrm{eq}}}=\frac{\mathrm{C}-1}{\mathrm{CX}} \mathrm{a}_{\mathrm{w}}+\frac{1}{\mathrm{CX}}
\end{aligned}
$$

Equation $\{($ Eq.10) $\}$ can easily be transformed into a linear equation having the following form:

$$
\frac{a_{w}}{\left(1-a_{w}\right) X_{e q}}=A a_{w}+B
$$

Where:

$$
\mathrm{A}=\frac{\mathrm{C}-1}{\mathrm{CX}} \quad \text { and } \quad \mathrm{B}=\frac{1}{\mathrm{CX}_{\mathrm{m}}}
$$

A linearization of the curve $f\left(a_{w}\right)=\frac{a_{w}}{\left(1-a_{w}\right) X_{e q}}$ by the least squares method, allows determining the slope (A) and the ordinate at the origin (B). The $\mathrm{Xm}$ and $\mathrm{C}$ parameters are then determined by the following relationships:

We know that: $f\left(a_{\mathrm{u}}\right)=\frac{\mathrm{a}_{\mathrm{w}}}{\left(1-\mathrm{a}_{\mathrm{w}}\right) \mathrm{X}_{\mathrm{eq}}}$ 


$$
\begin{aligned}
& X_{m}=\frac{1}{(A+B)} \\
& \mathrm{C}=\frac{\mathrm{A}+\mathrm{B}}{\mathrm{B}}
\end{aligned}
$$

Xeq: equilibrium moisture content (g water/g ms), Xm: BET monolayer moisture content ( $\mathrm{g}$ water/g ms), C: BET constant related

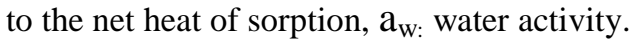

\section{- Smith (1947)}

It's an equation with two parameters frequently used to simulate the isotherms of the biological products. It is form:

$$
\mathrm{X}_{\mathrm{eq}}=\mathrm{K}_{1}-\mathrm{K}_{2} \ln \left(1-\mathrm{a}_{\mathrm{w}}\right)
$$

In the same order of idea a linearization of the curve $X_{e q}=f\left(\ln \left(1-a_{W}\right)\right)$ allows determining the constants $K_{1}$ and $K_{2}$ of the equation.

\section{- Henderson equation (1952)}

It is an empirical equation developed by Henderson and which is written as follows:

$$
\ln \left(1-\mathrm{a}_{\mathrm{w}}\right)=-\mathrm{K}_{1} \mathrm{~T}\left(\mathrm{X}_{\mathrm{eq}}\right)^{\mathrm{K}_{2}} \text { ou } \quad \mathrm{X}_{\mathrm{eq}}=\left[\frac{-1}{\mathrm{~T} \mathrm{~K}_{1}} \ln \left(1-\mathrm{a}_{\mathrm{w}}\right)\right]^{\frac{1}{\mathrm{~K}_{2}}}
$$

A linearization of the curve $\ln \left[-\ln \left(1-a_{w}\right)\right]=\mathrm{f}(\mathrm{Xeq})$ by least squares allows determining the constants $\mathrm{K}_{1}$ and $\mathrm{K}_{2}$ of the model.

\section{- Iglesias and Chirife (1982)}

In the study of the behaviour in moisture sorption of rich foods in glucides where there is dissolution of sugars, these authors propose the following empirical equation:

$$
\mathrm{X}_{\mathrm{eq}}=\mathrm{K}_{1}\left(\frac{\mathrm{a}_{\mathrm{w}}}{1-\mathrm{a}_{\mathrm{w}}}\right)+\mathrm{K}_{2}
$$

A linearization of the curve $X_{e q}=f\left(\frac{a_{w}}{1-a_{n}}\right)$ by least squares allows determining the constants $\mathrm{K}_{1}$ and $\mathrm{K}_{2}$ of the model.

\section{- GAB Model (19851)}

This model not only allows calculating monolayer moisture content, but also the heat sorption of monolayer and multilayer. It is applicable for the water activities ranging between 0.05 and 0.95 (Ferradji et al, 2008). The GAB equation is given by the following equation (Kiranoudis et al., 1993): 


$$
X_{e q}=\frac{X_{m} C K a_{w}}{\left(1-K a_{w}\right)\left(1-K a_{w}+C K a_{w}\right)}
$$

Where:

$\mathrm{Xm}=\mathrm{GAB}$ monolayer moisture content ( $\mathrm{g}$ moisture/gms), $\mathrm{C}=$ constant related to the monolayer heat of sorption, $\mathrm{K}=$ factor related to the heat of sorption of the multilayer. This equation has a similar form to BET, but has an extra constant K. BET is actually a special case of $\mathrm{GAB}$, where $\mathrm{K}=1$. The $\mathrm{GAB}$ parameters were determined following the method of the transformed form of the GAB isotherm (Timmermann et al., 2003). The GAB model can be rearranged to a polynomial equation as follows:

$$
\frac{a_{w}}{X_{e q}}=\frac{K}{X_{m}\left(\frac{1-C}{C}\right)} a_{w}^{2}+\frac{C-2}{X_{m} C} a_{w}+\frac{1}{X_{m} K C}
$$

The equation $\{($ Eq.18) $\}$ can be represented by the form:

$$
\frac{\mathrm{a}_{\mathrm{w}}}{\mathrm{X}_{\mathrm{eq}}}=\alpha \mathrm{a}_{\mathrm{w}}{ }^{2}+\beta \mathrm{a}_{\mathrm{w}}+\varepsilon
$$

Where:

$$
\alpha=\frac{\mathrm{K}}{\mathrm{X}_{\mathrm{m}}\left(\frac{1-\mathrm{C}}{\mathrm{C}}\right)} ; \quad \beta=\frac{\mathrm{C}-2}{\mathrm{X}_{\mathrm{m}} \mathrm{C}} ; \quad \varepsilon=\frac{1}{\mathrm{X}_{\mathrm{m}} \mathrm{KC}}
$$

A polynomial direct nonlinear regression method of $\mathrm{a}_{\mathrm{w}} / \mathrm{Xeq}$ versus aw was carried out using Microsoft Excel (2010) software in order to determine the values of the coefficient of the quadratic term $\alpha$, the linear term coefficient $\beta$ and the constant $\varepsilon$. Then the GAB parameters were calculated as follows:

$$
\begin{aligned}
& K=\frac{\sqrt{\mathrm{f}}-\beta}{2 \varepsilon} \\
& X_{\mathrm{m}}=\frac{1}{(\beta+2 \mathrm{K \varepsilon})} \\
& \mathrm{C}=2+\frac{\beta}{\mathrm{K} \varepsilon}
\end{aligned}
$$

Where: $\mathrm{f} \equiv \beta^{2}-4 \alpha \varepsilon$

\section{Thermodynamic properties}

\section{- Determination of Isosteric Heat of Sorption}

Clausius-Clapeyron equation, because of its theoretical basis, is often used in determining the total heat of sorption (Qst) of agricultural products (Iglesias and Chirife, 1976; Kiranoudis et al., 1993; Shittu et al., 2015). At a constant amount of sorbed water, the equation is expressed as follows:

$$
\left.\frac{\mathrm{dln} P}{\mathrm{dT}}\right|_{\mathrm{X}}=\frac{\mathrm{Qst}}{\mathrm{R}_{\mathrm{O}} \mathrm{T}^{2}}
$$

Where $\mathrm{P}$ is the water vapour pressure of the product at the specified temperature, $\mathrm{T}$, and Ro is the universal gas constant. 
For pure water at state free, the equation $\{($ Eq. 23)\} becomes

$$
\frac{\mathrm{d} \ln \mathrm{P}_{\mathrm{O}}}{\mathrm{dT}}=\frac{\mathrm{Lv}}{\mathrm{R}_{\mathrm{O}} \mathrm{T}^{2}}
$$

Where Po is the saturation water vapour pressure at the temperature $\mathrm{T}$ and $\mathrm{Lv}$ is the heat of vaporization of pure water at state free. Subtracting equation $\{($ Eq.24) $\}$ from equation $\{$ (Eq. 23) $\}$ yields:

$$
\left.\frac{\mathrm{d} \ln \frac{\mathrm{P}}{\mathrm{P}_{\mathrm{O}}}}{\mathrm{dT}}\right|_{\mathrm{X}}=\left.\frac{\mathrm{dln} \mathrm{a}_{\mathrm{w}}}{\mathrm{dT}}\right|_{\mathrm{X}}=\frac{\mathrm{q}_{\mathrm{st}}}{\mathrm{R}_{\mathrm{O}} \mathrm{T}^{2}}
$$

Where:

qst $=$ Qst $-\mathrm{L}_{\mathrm{v}}$, is the net isosteric heat of sorption $(\mathrm{kJ} / \mathrm{mol})$ with equilibrium moisture content ( $\mathrm{g}$ water $\left./ \mathrm{ms}\right)$. Integrating equation $\{($ Eq. 25$)\}$ yields

$$
\ln \mathrm{a}_{\mathrm{w}}=\left(\frac{-\mathrm{q}_{\mathrm{st}}}{\mathrm{R}_{\mathrm{O}}}\right) \frac{1}{\mathrm{~T}}+\mathrm{C}_{\mathrm{st}}
$$

The chart representation of the curve $-\ln \left(a_{w}\right)=f(1 / T)$ with one moisture content constant with the value of $R$ near, enables us to determine the slope $-\mathrm{q}_{\mathrm{st}} / \mathrm{R}_{\mathrm{o}}$ and the constant integration Cst. Slope of isosteric and for each moisture content Xeq, we can deduce the corresponding net isosteric heat and plot the curve qst $=\mathrm{f}(\mathrm{Xeq})$.

A mathematical model which expresses the total heat of sorption as function of moisture was developed by Gallagher (1951) and is commonly cited in the literature (Shittu et al., 2015). The equation is given as follows:

$$
\text { Qst }=\operatorname{Lv}[\operatorname{aexp}(b \operatorname{Xeq})]
$$

According to Tsami et al. (1990), one exponential empirical correlation $\{(\mathrm{Eq} .27)\}$ can be established to describe a relation between the isosteric heat of desorption and the equilibrium moisture content.

$$
q_{s t}=q_{o} \exp \left(-\frac{X_{e q}}{X_{o}}\right)
$$

Where:

qo is the isosteric heat of sorption of the first molecule of water in the foods $(\mathrm{kJ} / \mathrm{mol})$; Xo is a characteristic moisture content $(\mathrm{g}$ water/g ms) of the food material; it is the moisture content at which the net isosteric heat of desorption has been reduced by $63 \%$ (Kiranoudis et al., 1993).

\section{- Enthalpy-Entropy compensation theory}

The change in molar differential entropy was calculated from Gibbs-Helmholtz equation.

$$
\Delta s=-\frac{\mathrm{q}_{\mathrm{st}}-\Delta \mathrm{G}}{\mathrm{T}}
$$




$$
\Delta \mathrm{G}=\mathrm{RT}_{\mathrm{O}} \ln \left(\frac{\mathrm{P}}{\mathrm{P}_{0}}\right)=\mathrm{RT}_{\mathrm{O}} \ln \left(\mathrm{a}_{\mathrm{w}}\right)
$$

$\mathrm{G}$ is the free energy $\left(\mathrm{kJ} \mathrm{mol}^{-1}\right)$ and $\Delta \mathrm{s}$ is the differential entropy $\left(\mathrm{kJ} \mathrm{mol}^{-1} \mathrm{~K}^{-1}\right)$. Combining $\{(\mathrm{Eq} .29)\}$ and $\{(\mathrm{Eq} .30)\}$ gives a final relationship:

$$
\ln \left(\mathrm{a}_{\mathrm{w}}\right)=-\frac{\mathrm{q}_{\mathrm{st}}}{\mathrm{RT}_{\mathrm{O}}}+\frac{\Delta \mathrm{s}}{\mathrm{R}}
$$

The values of qst and $s$ were calculated from the slope of the line when $\ln (\mathrm{aw})$ was plotted against $1 / \mathrm{T}$ at different constant moisture contents, (qst/R) and the intercept ( $\mathrm{s} / \mathrm{R})$, respectively. The Enthalpy-entropy compensation theory assumes that a linear relationship exists between enthalpy and entropy as follows:

$$
\mathrm{q}_{\mathrm{st}}=\mathrm{T}_{\beta}(\Delta \mathrm{S})+\Delta \mathrm{G}_{\beta}
$$

The value of $T \beta$, which is the isokinetic temperature $(\mathrm{K})$ and $G \beta$, which is the free energy at the isokinetic temperature were calculated from linear regression of qst against $G \beta$ values.

The isokinetic temperature $T \beta$ represents the temperature at which all reactions in the series proceed at the same rate, and GB is a criterion to determine whether water vapor sorption process for material is a spontaneous (- $G)$ is or non-spontaneous process (+ G). $T \beta$ and $G \beta$ are obtained by plotting the curve $q s t=\mathrm{f}(S)$.

Krug et al. (1976) and Madamba et al. (1996) recommended a test for the compensation theory, which involves comparing the isokinetic temperature with the harmonic mean temperature Thm, which is defined as (Goula et al., 2008 ; Giraldo et al., 2011):

$$
T h_{m}=\frac{n}{\sum_{i=1}^{n}\left(1 / T_{n}\right)}
$$

Where:

$\mathrm{n}$ is the total number of isotherm. $\mathrm{T} \beta$ is calculated by linear regression for all the sets of data with a confidence interval of $95 \%$ :

$$
T_{\beta}=T_{\beta} \pm \frac{t_{m-2 \alpha}}{2 \sqrt{\operatorname{Var}\left(T_{\beta}\right)}}
$$

Where:

$$
\begin{aligned}
& T_{\beta}=\frac{\sum\left(q_{s t}-\overline{q_{s t}}\right)(\Delta S-\overline{\Delta S})}{(\Delta S-\overline{\Delta S})^{2}} \\
& \operatorname{Var}\left(T_{\beta}\right)=\frac{\sum\left(q_{s t}-\overline{\Delta G_{\beta}}-T_{\beta} \Delta S\right)^{2}}{(m-2) \sum(\Delta S-\overline{\Delta S})^{2}}
\end{aligned}
$$

$\mathrm{m}$ is the number of $\left(q_{s t}, S\right)$ even of data, $\left(\overline{q_{s t}}\right)$ is the mean enthalpy, and is $(\overline{\Delta S})$ the mean entropy. 


\section{- Activation Energy}

The activation energy is the free enthalpy which separate from the state energy transition and that of the initial state. The energy activation is roughly constant in a given interval of temperature. The temperature dependency of the GAB parameters was given by the following Arrhenius-type equations (Akoy et al., 2013):

$$
\begin{aligned}
& \mathrm{K}=\mathrm{K}_{\mathrm{o}} \exp \frac{\Delta \mathrm{H}_{\mathrm{k}}}{\mathrm{RT}_{\mathrm{abs}}} \\
& \mathrm{C}=\mathrm{C}_{\mathrm{o}} \exp \frac{\Delta \mathrm{H}_{\mathrm{C}}}{\mathrm{RT}_{\mathrm{abs}}} \\
& \mathrm{X}_{\mathrm{m}}=\mathrm{X}^{\mathrm{O}} \exp \left(\frac{-\mathrm{E}_{\mathrm{a}}}{\mathrm{RT}_{\mathrm{abs}}}\right)
\end{aligned}
$$

Where:

Co, Ko and $X^{O}$ are adjustable constants for the temperature effect;

$\mathrm{R}=$ universal gas constant, $8.314 \mathrm{~J} / \mathrm{mol} / \mathrm{K}$

Tabs $=$ absolute temperature, $\mathrm{K}$

$\mathrm{Ea}=$ activation energy, $\mathrm{KJ} / \mathrm{mol}$

For the monolayer moisture content, an Arrhenius - type equation was calculated using a linearised form of Equation $\{($ Eq. 40$)\}$

$$
\ln \left(X_{m}\right)=\ln \left(X^{0}\right)+\left(\frac{-E_{a}}{R_{a b s}}\right)
$$

The coefficient of Equation (40) can be easily obtained by plotting on an $\ln \left(X_{m}\right)$ versus $1 / T_{a b s}$ diagram. The Ea and $X_{m}$ coefficient can subsequently be related to the temperature by applying the regression technique. Ea was calculated by plotting $\ln \left(\mathrm{X}_{\mathrm{m}}\right)$ versus the reciprocal of the absolute temperature. The slope of the curves found by applying the linear regression yields the coefficient $\mathrm{Ea} / \mathrm{R}$, while the intercept is equal to $\ln \left(X^{O}\right)$.

\section{Statistical analyses}

The modelization of desorption isotherms requires the statistical analysis methods of regression and correlation to assert the best results obtained, without a great margin of error. The regression analysis is carried out, under the software Excel 2010, by using the method of least squares. The coefficient correlation ( $r$ ) was the first criterion of selection of the best equation to describe the curves of desorption. In addition to the calculation of $r$, calculations of the values of EMR (Relative Average Error), EST (Standard Error of the Moisture Content) and ei (Residual Error) have allowed to justify the choice of the model. The residual error allows knowing if the residues between the values predicted and experimental are tiny. The best model is that which presents the greatest value close to (r) and the smallest values of errors EMR, EST and Ei (Benhamou et al., 2010). These statistical parameters are calculated as follows:

$$
\begin{aligned}
& r=\left[\frac{\sum_{i=1}^{n}\left(X_{e q_{i}} \text { pre }-\overline{X_{e q_{i}}}, \text { exp }\right)^{2}}{\sum_{i=1}^{n}\left(X_{e q_{i}} \exp -\overline{X_{e q_{i}}}, \exp \right)^{2}}\right]^{\frac{1}{2}} \\
& E S T=\left[\frac{\sum_{i=1}^{n}\left(X_{e q_{i},} \exp -X_{e q_{i}} p r e\right)^{2}}{d f}\right]^{\frac{1}{2}} \\
& E M R=\frac{100}{N} \sum_{i=1}^{N}\left|\frac{X_{e q_{i,}} \text { exp }-X_{e q_{i,}}, p r e}{X_{e q_{i},} \text { exp }}\right| \\
& E i=X_{e q_{i,}} \exp -X_{e q_{i,},} \text { pre }
\end{aligned}
$$


Where:

Xeq $i^{\prime}$ exp: $\mathrm{i}^{\mathrm{em}}$ equilibrium moisture content experimental; Xeq $i^{\prime}$ pre: $\mathrm{i}^{\mathrm{em}}$ equilibrium moisture content predicted; $\mathrm{N}$ : number experimental points, $\{$ in our case, $\mathrm{N}=9\}$ and $\mathrm{df}$ are degree of freedom of the regression model $\{\mathrm{df}=\mathrm{N}-\mathrm{n}\}$ where $\mathrm{n}$ indicates the number of constants of each model.

\section{Results and discussion}

- Obtaining the points of desorption isotherms

The hygroscopic equilibrium of desorption of the powder is reached at the end of 27 days for the last points of the curve. The values of equilibrium moisture content experimental (Xeq) are presented in the Table 2.

Table 2. Equilibrium moisture content, $\mathrm{Xeq}$ (g moisture/g ms) of desorption isotherms

\begin{tabular}{cccccccc}
\hline \multicolumn{2}{c}{$\mathbf{T}=\mathbf{3 0}{ }^{\circ} \mathbf{C}$} & \multicolumn{2}{c}{$\mathbf{T}=\mathbf{3 5}{ }^{\circ} \mathbf{C}$} & \multicolumn{2}{c}{$\mathbf{T}=\mathbf{4 5}{ }^{\circ} \mathbf{C}$} & \multicolumn{2}{c}{$\mathbf{T}=\mathbf{5 5}{ }^{\circ} \mathbf{C}$} \\
\hline $\mathbf{a}_{\mathbf{w}}$ & $\mathbf{X e q}$ & $\mathbf{a}_{\mathbf{w}}$ & $\mathbf{X e q}$ & $\mathbf{a}_{\mathbf{w}}$ & $\mathbf{X e q}$ & $\mathbf{a}_{\mathbf{w}}$ & $\mathbf{X e q}$ \\
6.20 & 5.24 & 6.00 & 4.3 & 5.7 & 2.71 & 5.40 & 2.01 \\
7.20 & 5.52 & 6.70 & 4.81 & 5.9 & 2.81 & 5,60 & 2.11 \\
11.30 & 6.11 & 11.30 & 5.31 & 11.2 & 4.01 & 11.00 & 3.02 \\
32.40 & 7.8 & 32.10 & 6.93 & 31.1 & 5.73 & 29.90 & 4.89 \\
61.80 & 12.8 & 58.60 & 11.00 & 52.6 & 8.9 & 51.00 & 6.61 \\
67.89 & 14.6 & 66.96 & 13.5 & 65.6 & 11.5 & 63.78 & 9.39 \\
75.10 & 17.00 & 74.90 & 16.09 & 74.5 & 14.09 & 74.40 & 12.09 \\
83.60 & 21.00 & 83.00 & 19.42 & 81.7 & 17.42 & 80.70 & 14.82 \\
97.00 & 28.00 & 96.70 & 26.37 & 96.1 & 24.37 & 95.40 & 22.87 \\
\hline
\end{tabular}

On this Table 2, on observes with the increase of the temperature, it occurs, a reduction of the moisture content, which means that the product becomes less hygroscopic. That can be explained by the increase of thermic agitation (binding energy of high moisture); indeed, for high temperatures, the state of excitation of the water molecules is more significant, involving a reduction of the attraction forces of the water molecules between them (Benhamou et al., 2010; Shittu et al., 2015).

\section{- Modelization of the desorption isotherms}

Table 3 presents the statistical parameters and the coefficients of the models used. A simple analysis of the five statistical models shows that the model of GAB with 5 parameters is the most suitable for describing the desorption isotherms of the powder. This model presents the highest correlation coefficients ' $r$ ' $(r=1)$ and the lowest EST and EMR values. These results are in agreement with the work realized on desorption isotherms where the GAB model simulated better, on a broad range of water activity, experimental data of the authors hereafter : Ferradji et al. (2008); Ahouannou et al. (2010) ; Kakou et al. (2015). The monolayer moisture contents of BET and $\mathrm{GAB}$ models are dependent on the temperature with values relatively very close, respectively 0.0632024 and 0.07234577 at $30{ }^{\circ} \mathrm{C} ; 0.0512334$ and 0.06001235 at $35{ }^{\circ} \mathrm{C} ; 0.05109112$ and 0.05882823 at $45{ }^{\circ} \mathrm{C} ; 0.04212803$ and 0.0465500021 at $55^{\circ} \mathrm{C}$. At these values of the water content of the monomolecular layer, the chemical reactions of deterioration are weak and the stability of the product is satisfactory during storage.

The curves of desorption isotherms which result from three theoretic models are confronted with the experimental points and are illustrated on the figure 3. The values of the parameter $\mathrm{C}$ of $\mathrm{GAB}$ equation in the table 3 allows to characterize the isotherms of sorption. According to Medeiros et al. (2006), when C $\leq 10$, the isotherm is type III whereas for C $\geq 10$, the isotherm is type II. In this study, the values of the parameter $\mathrm{C}$ are higher than 10 whatever the temperature. Thus, the isotherms of desorption obtained are type II. They are thus of sigmoidal form. That implies a formation of monolayer then multilayer. This type of isotherm is characteristic of the hygroscopic behavior of the majority of the foodstuffs (Kakou et al., 2015). These results are in agreement with the behavior of the biological products (Iglesias and Chirife, 1982; Ahouannou et al., 2010). The positive value of the parameter $\mathrm{K}$ of $\mathrm{GAB}$, whatever the temperature, indicates that the heat of sorption of multilayer is lower than the latent heat of condensation of pure water.

On this Figure 3, we observe that the theoretical curves obtained coincide properly with the experimental results. The theoretical models GAB is quite satisfactory to reproduce theoretically the isotherms desorption of the powder in the field drive of the water activities from 5.4 to $97 \%$. The BET model presents a perfect simulation with the experimental curve but in the beach of water activities lower than 0.35 . It is possible to observe on the isotherms reproduced by the GAB model that three zones are identifiable (Figure 4): 
Monolayer Zone (zone 1): Constitution of one monolayer molecular on the surface of the product. It is characteristic of the action of the forces of Van Der Waals between the absorbent groupings and the water molecules. The adsorption of the water molecules is done gradually until constituting one monolayer covering all external surface and one part of the pores of the product. Water is in a rigid state because of the importance of the bonding strengths between the water molecules and surface. The passage to the following zone is carried out when all surfaces is saturated;

Multilayer Zone (zone 2): Adsorption of the molecules on the initial monolayer. The isotherm is linear in this zone and water is in an intermediate state between solid and liquid.

Zone of free water and of the solvation (Zone 3): Water is present in the liquid state in the pores of material. The thickness of the film is sufficient so that water is present at the liquid state in the pores of material. Water microcapillaire constitutes a continuous phase.

The residual curves resulting from the confrontation of the experimental points and the theoretical curves of GAB (Figure 4) are almost coincident with the $\mathrm{x}$-axis, which confirms the effectiveness of the model selected.

Table 3. Values of the estimated parameters and statistical criteria of choice

\begin{tabular}{|c|c|c|c|c|c|c|}
\hline $\mathbf{T}\left({ }^{\circ} \mathbf{C}\right)$ & & $\begin{array}{c}\text { GAB } \\
(\mathrm{n}=5)\end{array}$ & $\begin{array}{c}\text { BET } \\
(n=2)\end{array}$ & $\begin{array}{l}\text { Smith } \\
(n=2)\end{array}$ & $\begin{array}{c}\text { Henderson } \\
(\mathrm{n}=2)\end{array}$ & Iglésias $(n=2)$ \\
\hline \multirow{10}{*}{30} & $\mathbf{X m}$ & 0.07234577 & 0.0632024 & - & - & - \\
\hline & $\mathbf{C}$ & 17.2328262 & 19.1236674 & - & - & - \\
\hline & $\mathbf{K}$ & 0.72341254 & - & - & - & - \\
\hline & Co & 21.012354623 & - & - & - & - \\
\hline & Ko & $3.1264 \mathrm{E}-19$ & - & - & - & - \\
\hline & K1 & - & - & 0.0623023 & 0.7208221 & 0.00833221 \\
\hline & K2 & - & - & 0.0097865 & 1.82323423 & 0.11208688 \\
\hline & $\mathbf{R}$ & 1 & 0.9832354 & 0.9845354 & 0.98428792 & 0.9892345 \\
\hline & EST & 0.0000011 & 0.940612 & 0.8651634 & 0.01470782 & $8.12876 \mathrm{E}-07$ \\
\hline & EMR & 0.0000409 & 0.024527546 & 0.2628456 & 0.43527920 & 0.076544236 \\
\hline \multirow{10}{*}{35} & $\mathbf{X m}$ & 0.06001235 & 0.0512334 & - & - & - \\
\hline & $\mathbf{C}$ & 16.2347865 & 35.1231237 & - & - & - \\
\hline & $\mathbf{K}$ & 0.967432132 & - & - & - & - \\
\hline & Co & 23.01217862 & - & - & - & - \\
\hline & Ko & $4.876123 \mathrm{E}-19$ & - & - & - & - \\
\hline & K1 & - & - & 0.032322312 & 0.87211132 & 0.006879534 \\
\hline & K2 & - & - & 0.08762845 & 1.92895432 & 0.1028222 \\
\hline & $\mathbf{R}$ & 1 & 0.9924578 & 0.988999966 & 0.97375255 & 0.951 \\
\hline & EST & 0.000001 & 11.86 & 4,88829E-4 & 0.02187081 & 0.00012117 \\
\hline & EMR & 0.000031932 & 0.197408235 & $1.67626 \mathrm{E}-03$ & 0.88666122 & 0.45409213 \\
\hline \multirow{10}{*}{45} & $\mathbf{X m}$ & 0.05882823 & 0.05109112 & - & - & - \\
\hline & C & 17.4321656 & 26.3218765 & - & - & - \\
\hline & $\mathbf{K}$ & 0.92121212 & - & - & - & - \\
\hline & Co & 9.00040121 & - & - & - & - \\
\hline & Ko & $2.1265 \mathrm{E}-18$ & - & - & - & - \\
\hline & K1 & - & - & 0.03271906 & 0.1215134 & 0.0035338 \\
\hline & K2 & - & - & 0.09111536 & 1.81182134 & 0.012754211 \\
\hline & $\mathbf{R}$ & 1 & 0.995678 & 0,98901159 & 0.98991111 & 0.99666612 \\
\hline & EST & 0.0002309 & 7.8883233 & $1.1111 \mathrm{E}-03$ & 0.0212412 & $4.12828 \mathrm{E}-07$ \\
\hline & EMR & 0.0003215 & 0.32145676 & 0.001219342 & 0.33343216 & 0.001277732 \\
\hline \multirow{10}{*}{55} & $\mathbf{X m}$ & 0.0465500021 & 0.04212803 & - & - & - \\
\hline & $\mathbf{C}$ & 25.12546232 & 31.6023241 & - & - & - \\
\hline & $\mathbf{K}$ & 0.93794311 & - & - & - & - \\
\hline & Co & 10.9024605 & - & - & - & - \\
\hline & Ko & $3.123298 \mathrm{E}-11$ & - & - & - & - \\
\hline & K1 & - & - & 0,02634887 & 1.21721762 & 0.0100649 \\
\hline & K2 & - & - & 0,07717861 & 2.00976287 & 0.06971325 \\
\hline & $\mathbf{R}$ & 1 & 0.99989 & 0.9876512 & 0.71731644 & 0.63612342 \\
\hline & EST & 0 & 0.92998768 & 8.0324E-12 & 0.26719211 & 0.00922999 \\
\hline & EMR & 0 & 0.039485411 & $3.22241 \mathrm{E}-13$ & 4.99999777 & 4.88864321 \\
\hline
\end{tabular}


$\mathrm{n}=$ Number of model parameters
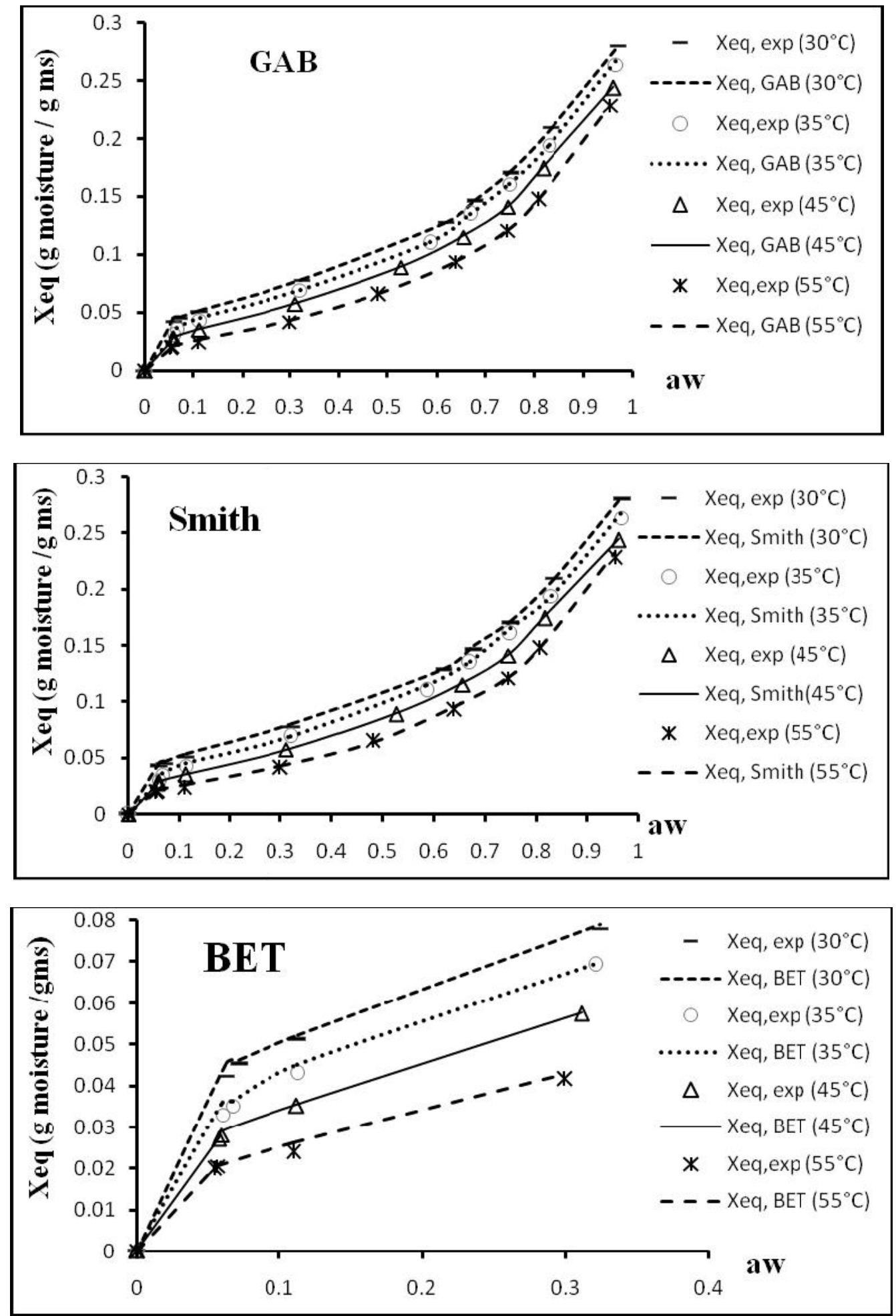

Figure 3: Experimental and modeled desorption curves of the powder. 

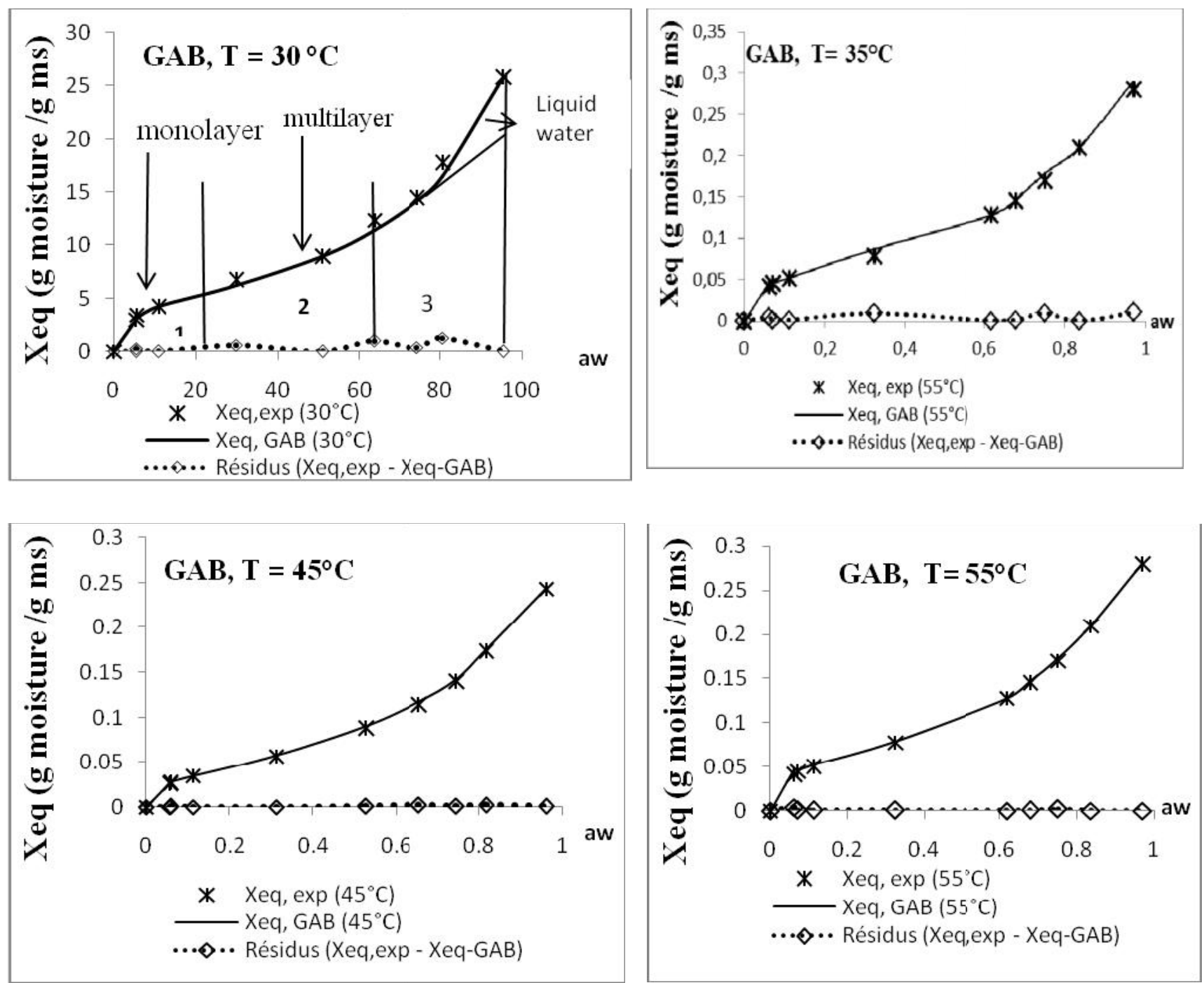

Figure 4. Curves of residues between the isotherms experimental and predicted by GAB

We also note that at the temperatures of $45^{\circ} \mathrm{C}$ and $55^{\circ} \mathrm{C}$ the residual curves between experimental isotherms and predicted by BET (Figure 5) are perfectly coincident with the $\mathrm{x}$-axis in the beach of the water activities ranging between 5.4 to $35 \%$.
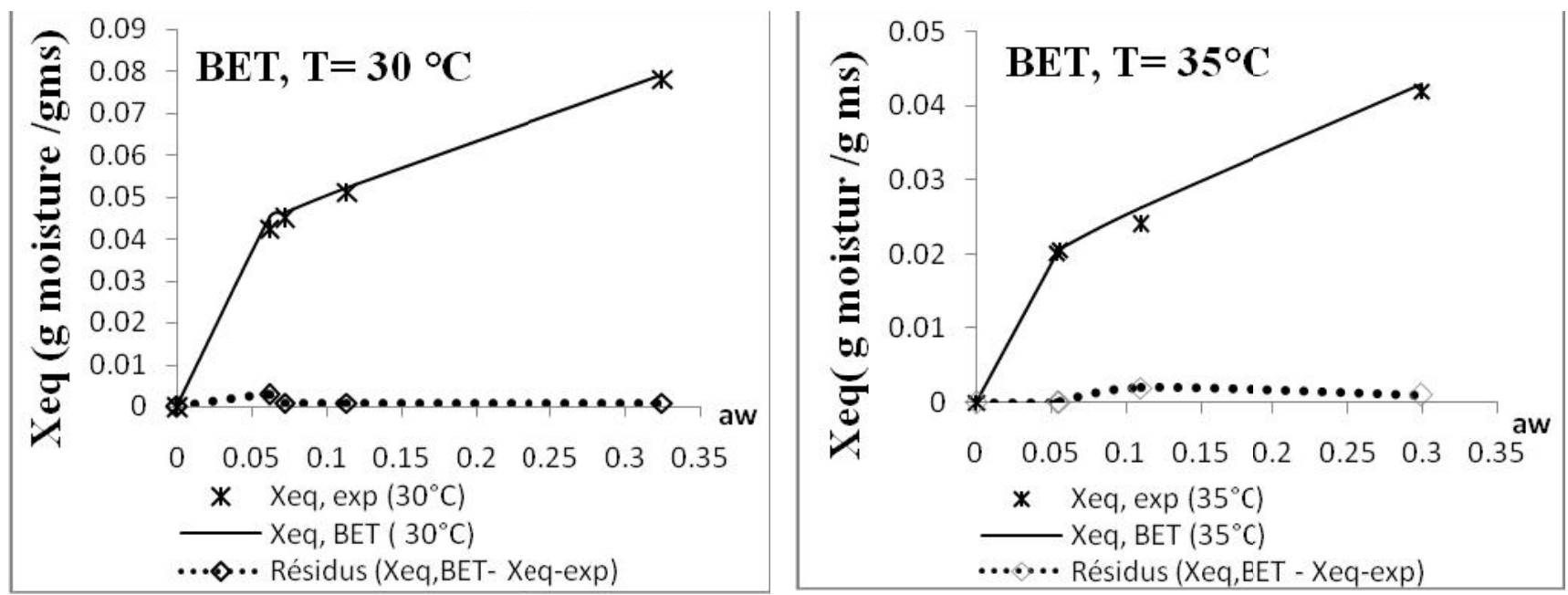

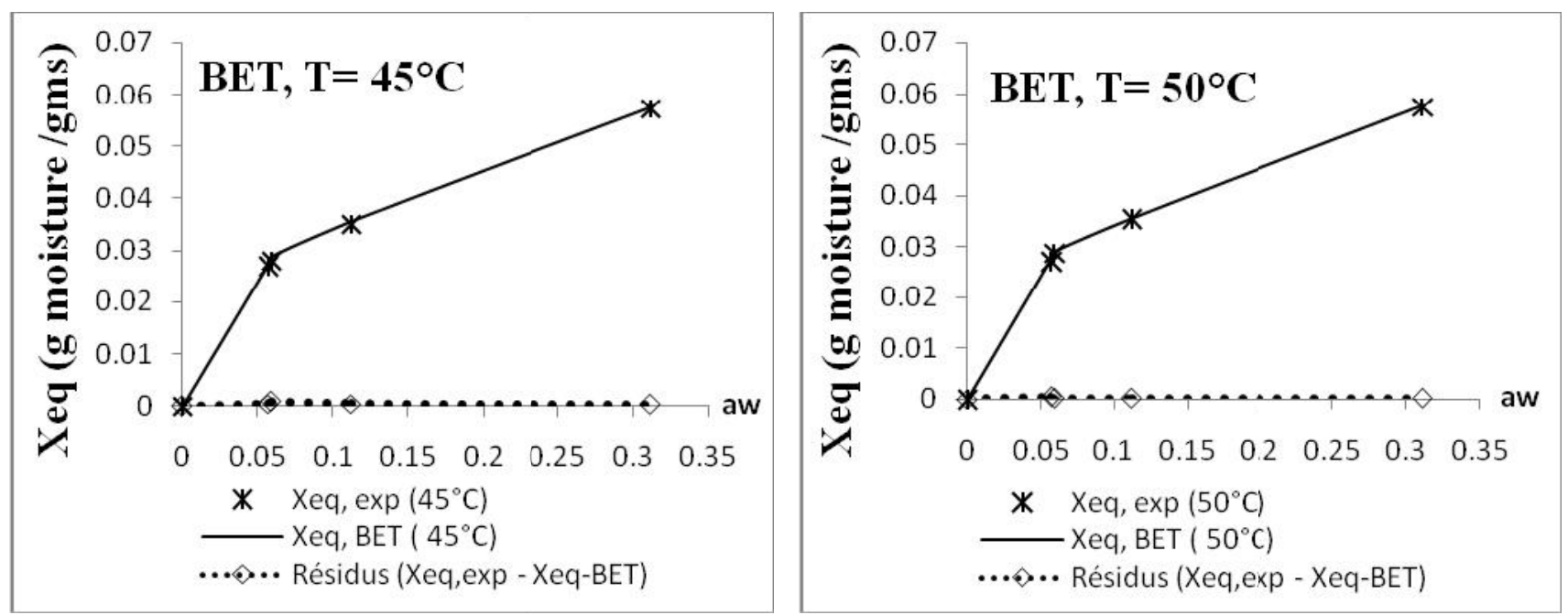

Figure 5. Residues curves between the isotherms experimental and predicted by BET

\section{- Thermodynamic properties}

\section{$\circ \quad$ Net isosteric heat and differential entropy}

The thermodynamic functions such as net isosteric heat (qst) and the differential entropy ( $\mathrm{S}$ ) calculated from desorption isostere (Figure 6) allows to evaluate the heat quantity necessary to dry the product.

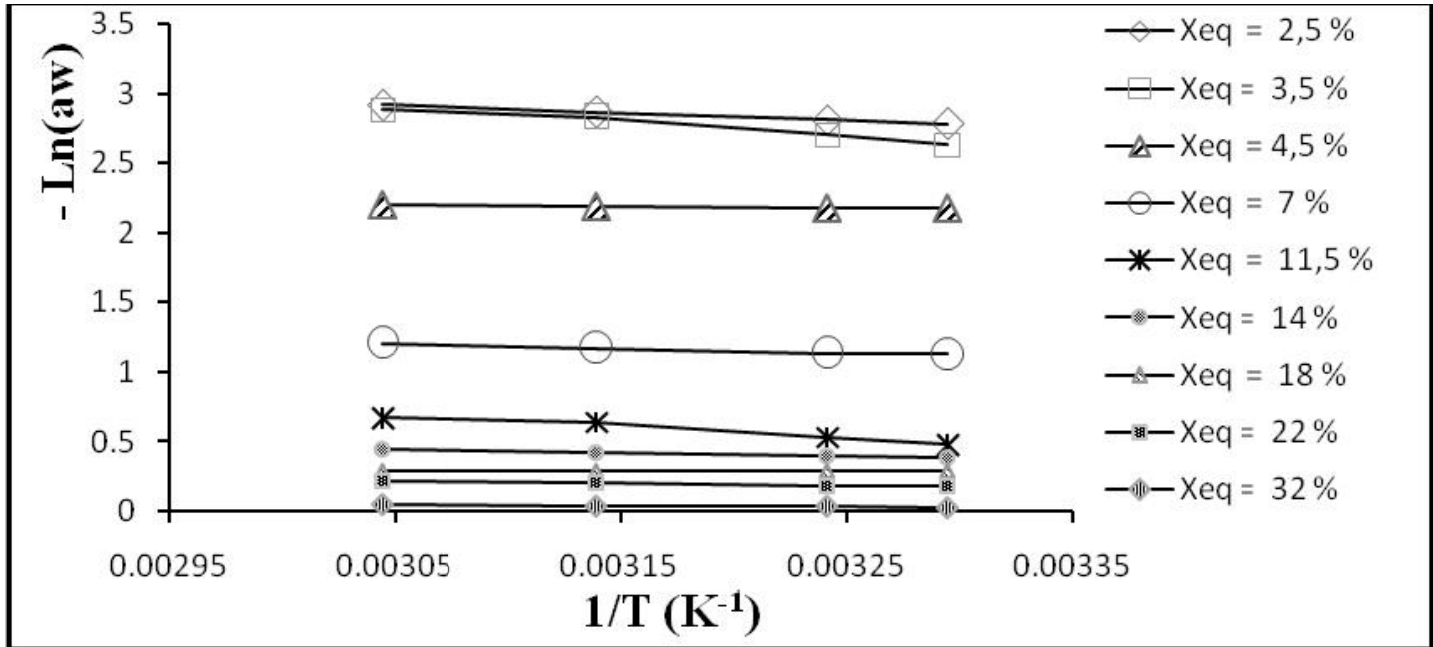

Figure 6. Variation logarithmic curve of aw according to the temperature reverse

It is noted that the variation logarithmic curve of the water activity $\left(a_{w}\right)$ according to the temperature reverse gives affine lines (isostere), which results in the existence of a proportionality between water activity and the temperature. The moisture content of the product is related to these two parameters. The Figure 7 presents the net isosteric heat (qst) and the differential entropy ( S) of desorption for the temperatures of 30 at $55^{\circ} \mathrm{C}$, according to moisture content. The experimental data of the net isosteric heat and the differential entropy were correlated with satisfaction $(\mathrm{R}=0.999)$ by the GAB model in its transformed form, represented by the equation $\{$ (Eq. (45) $\}$ :

$$
a_{w}=\left\lceil 2+\left(\frac{X_{m}}{X_{e q}}-1\right) * C-\left\{\left(2+\left(\frac{X_{m}}{X_{e q}}-1\right) * C\right)^{2}-4(1-C)\right\}^{\frac{1}{2}}\right\rceil /[2 K *(1-C)]
$$



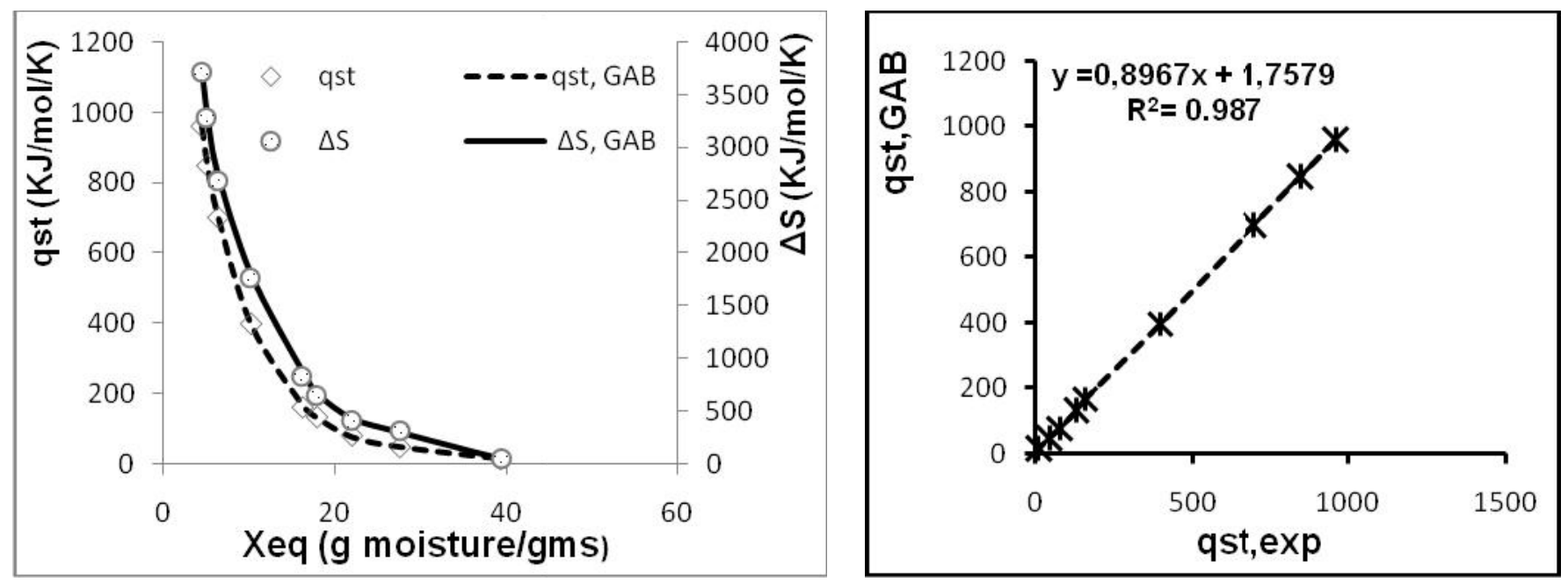

Figure 7. Isosteric heat and differential entropy experimental and predicted by GAB

These curves show that for higher moisture contents, the net isosteric heat (qst) and the differential entropy ( $\mathrm{S}$ ) desorption tends towards zero. That illustrates the strong contact of water with the substrate, the isosteric heat of desorption (qst) becomes negligible in front of the latent heat. The existence of polar sites of great activity in the powder which are covered with water molecules forming the monolayer (Tasmi et al., 1990) could explain this fact. According to other authors (Boki et al., 1990; Salgado et al., 1994), this phenomenon is due to the fact that in a very restricted field of moisture, when the moisture content increases, certain products inflate and favours the opening of new sites of adsorption of strong joining, which increases isosteric heat. The table 4 shows the values of Xo and qo of the empirical equation $\{($ Eq.24) $\}$.

Table 4. Values of Xo and qo for the powder

\begin{tabular}{lcccc}
\hline Parameters & $\mathrm{T}=30^{\circ} \mathrm{C}$ & $\mathrm{T}=35^{\circ} \mathrm{C}$ & $\mathrm{T}=45^{\circ} \mathrm{C}$ & $\mathrm{T}=55^{\circ} \mathrm{C}$ \\
\hline $\mathrm{X}_{\mathrm{o}}(\mathrm{g}$ moisture/gms $)$ & 0,06045362 & 0,05324156 & 0,05437890 & 0,0445980 \\
$q_{\mathrm{o}}(\mathrm{kJ} / \mathrm{mol})$ & 15,1323462 & 15,1895463 & 15,1267588 & 15,186534 \\
$\mathrm{r}^{2}$ & 0,97111232 & 0,975342 & 0,97232 & 0,99999 \\
\hline
\end{tabular}

In this Table 4, one observes with the increase in the temperature, it occurs a reduction in the moisture content characteristic (Xo).The net heat of isosteric desorption of the first water molecules in the product (qo) is almost constant with $16.3 \mathrm{~kJ} / \mathrm{mol}$ in the beach of temperatures tested. These results are comparable with those obtained by Kiranoudis et al. (1993) and Benseddik et al. (2014) for other foodstuffs. Indeed, the parameter qo provides significant information on the physicochemical interactions of water with the major components of product and the state of water in the product. It is about an essential parameter, for the estimate of the requirements in energy during drying (Benseddik et al, 2014).

\section{- Enthalpy-entropy compensation theory}

The qst and s, values for desorption, at given moisture contents, were calculated by linear regression equation using (Eq. (31)). It was assumed that, at specific moisture content, qst and s did not vary with temperature (Wang and Brennan, 1991). The plot of qst versus $\mathrm{s}$, for a product (Figure 8) shows a linear relation, with a coefficient of determination $\mathrm{r}=1$; this indicates that compensation exists. The values of the parameters $T \beta, G \beta$ (Eq. (32)) calculated from the data by linear regression are respectively of $300.12342 \mathrm{~K}$ and $(302.18 \mathrm{~J} / \mathrm{mol})$. The mean harmonic temperature $(\mathrm{Thm})$, determined starting from the equation (Eq. (33)) is $301.2435 \mathrm{~K}$. The Enthalpy-entropy compensation theory is largely applied to evaluate the physical and chemical phenomena which accompany the sorption reactions. This theory approves that the compensation between these two energies results from the natural changes of the interaction between the dissolved body and the solvent causing the reaction and that the relationship between the enthalpy and the entropy is linear (Arsalan and Torgrul, 2006; Benhamou et al., 2010). The values of T $\beta$ and Thm respectively $301.2435 \mathrm{~K}$ and $300.12342 \mathrm{~K}$ show that the enthalpic process is involved. The positive value of $G \beta$ obtained shows that the desorption process of the powder as well as the leaves is non-spontaneous (Benhamou et al., 2010). Indeed, according to Leffler (1995), if $\mathrm{T} \beta<\mathrm{Thm}$, the enthalpic process is involved, on the other hand if Thm $<\mathrm{T} \beta$, the process is regarded as controlled entropy. In fact, the process enthalpy-entropy compensation expresses the structuring-destructuring of water thermodynamically. The variation of the enthalpy corresponds to the variations of energy which occur between the water molecules and that of the matrix during the operations of sorption. Whereas the entropy defines the degree of order of the water adsorbed in the matter and allows the interpretation of some process, such as dissolution, crystallization and the expansion (Koumoutsakos and Avramidis, 1999; Fasina, 2006). The knowledge of the change of isosteric heat, and thus also of the change of 
differential entropy, calculated starting from the Gibbs-Helmholtz equation is interesting, because it offers an additional level of information to characterize the association of two molecules.

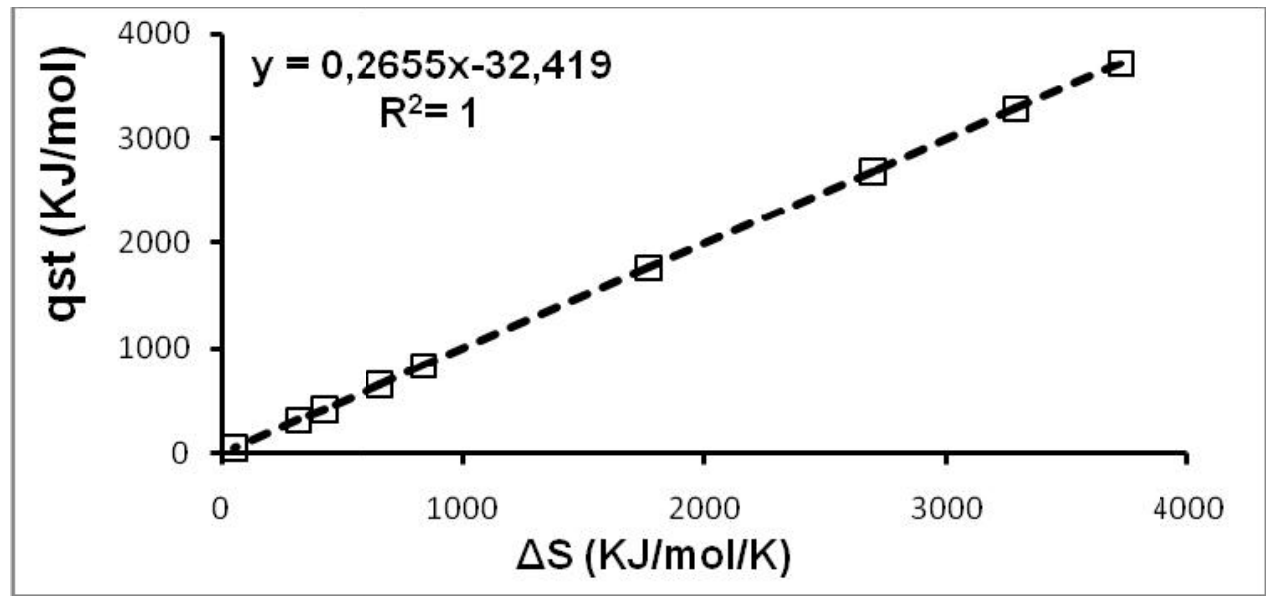

Figure 8. qst / s relationship for desorption of the powder

\section{- Activation Energy}

The logarithmic variation of the monolayer moisture content $(\mathrm{Xm})$ of GAB and BET as a function of the inverse of the temperature is illustrated by the Figures 9 and 10 .

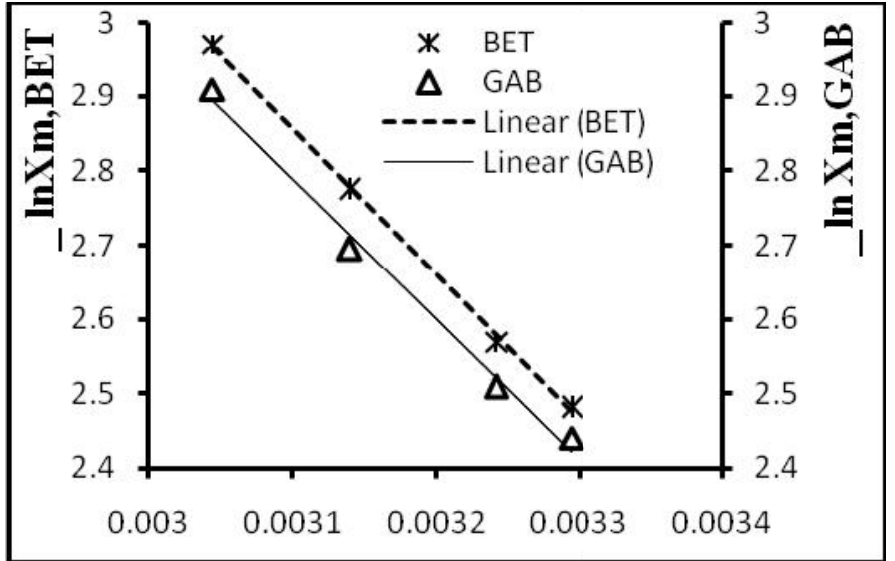

Figure 9. Variations logarithmic of Xm according to the temperature reverse.

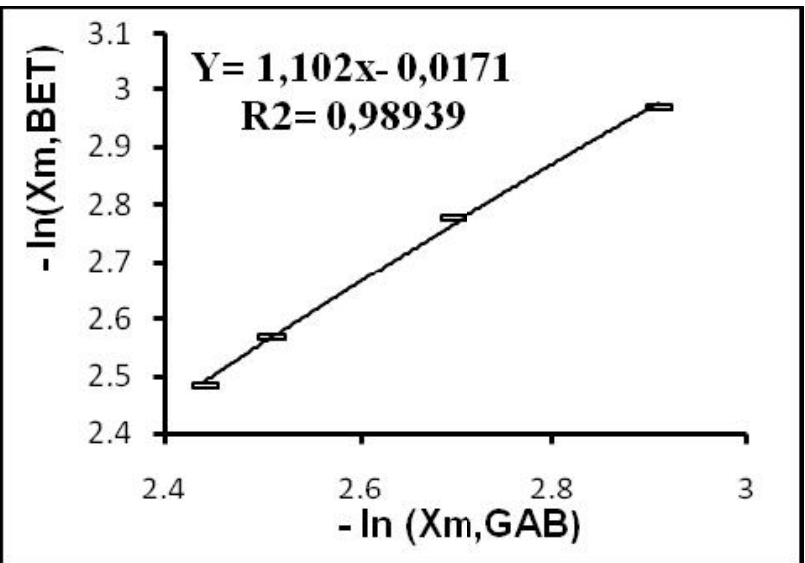

Figure 10. Confrontation between the neperian logarithm of (Xm, GAB) and (Xm, BET)

The values of the activation energy (Ea) given from the GAB or BET monolayer are respectively of $-10.1009539 \mathrm{~K} / \mathrm{mol}$ and $10.674442 \mathrm{~K} / \mathrm{mol}$ with a frequency collision respective $\left(\mathrm{X}^{\mathrm{O}}\right)$ of de 0.25646 and $0.20546 \% \mathrm{MS}$. Indeed, the negative values (Ea) obtained explain why the process of desorption of powder is exothermic. The bringing together of the variation logarithmic curve of GAB and BET monolayer $(\mathrm{Xm})$ gives a line closely connected translating by the existence of a proportionality between the monolayer $(\mathrm{Xm})$ of $\mathrm{GAB}$ and $\mathrm{BET}$ with a proportionality factor is equal to 1.066 and one coefficient of correlation $\mathrm{R}=0.996$.

\section{Conclusions}

The thermophysical properties of Moringa oleifera leaf powder were studied at four temperatures. The experimental results have shown that the curves of the desorption isotherms have a sigmoidal form of type II characterizing the hygroscopic media. One distinguishes three zones for these curves delimiting for each one a particular mode of fixing of water. The isothermal modeling results showed that the GAB model is most representative at 45 and $55^{\circ} \mathrm{C}$. The BET model also describes the desorption isotherms of the powder for humidities lower than $45 \%$. An exponential empirical correlation is established to describe the dependence of the sorption heat on the equilibrium water content. The enthalpy-entropy compensation and the isokinetic theory are successfully applied for the powder desorption, which shows that the desorption process of the powder is exothermic, non-spontaneous and is done by controlled enthalpic mechanisms. 


\section{Nomenclature}

\begin{tabular}{|c|c|c|}
\hline aw & Water activity & $(\%)$ \\
\hline $\mathrm{C}$ & BET constant related to the net heat of sorption & $(-)$ \\
\hline Df & Degree of freedom of the regression model & $(-)$ \\
\hline $\mathrm{Ea}$ & Activation energy & $(\mathrm{KJ} / \mathrm{mol})$ \\
\hline $\mathrm{Ei}$ & Residual Error & $(-)$ \\
\hline EMR & Relative Average Error & $(-)$ \\
\hline EST & Standard Error of the Moisture Content & $(-)$ \\
\hline $\mathrm{Hm}$ & Total heat of sorption of the monolayer & $(\mathrm{kJ} / \mathrm{mol})$ \\
\hline $\mathrm{Hn}$ & Total heat of sorption of the multilayer & $(\mathrm{kJ} / \mathrm{mol})$ \\
\hline $\mathrm{K}$ & Factor related to the heat of sorption of the multilayer & $(-)$ \\
\hline $\mathrm{K}_{1}, \mathrm{~K}_{2}$ & Models constants & $(-)$ \\
\hline Lv & Latent heat of condensation of water liquid, whether & $(\mathrm{kJ} / \mathrm{mol})$ \\
\hline $\mathrm{Me}$ & Equilibrium mass of the sample tested & (g) \\
\hline Ms & Mass anhydrous of the sample tested & (g) \\
\hline $\mathrm{N}$ & Number experimental points & $(-)$ \\
\hline $\mathrm{P}$ & Water vapour pressure of the product at the specified temperature, $\mathrm{T}$ & (atm) \\
\hline $\mathrm{Pv}$ & Vapor pressure at the surface of the product & (atm) \\
\hline Pvsat & Vapor pressure saturation at the temperature of the system & (atm) \\
\hline qo & Isosteric heat of sorption of the first molecule of water in the food & $(\mathrm{kJ} / \mathrm{mol})$ \\
\hline qst & Net isosteric heat and the differential entropy $(\mathrm{S})$ & $(\mathrm{kJ} / \mathrm{mol})$ \\
\hline $\mathrm{r}$ & Correlation coefficients & $(-)$ \\
\hline $\mathrm{R}$ & Universal gas constant & $(\mathrm{J} / \mathrm{mol} / \mathrm{K})$ \\
\hline $\mathrm{T}$ & Absolute temperature & $(\mathrm{K})$ \\
\hline Thm & Mean harmonic temperature & $(\mathrm{K})$ \\
\hline Ts & Equilibrium temperature of the system & $(\mathrm{K})$ \\
\hline $\mathrm{T} B$ & Isokinetic temperature & $(\mathrm{K})$ \\
\hline Xeq & Equilibrium moisture content of the sample & $(\% \mathrm{bs})$ \\
\hline Xeq i' pre & Equilibrium moisture content predicted & $(\% \mathrm{MS})$ \\
\hline Xeq i' exp & Equilibrium moisture content experimental & $(\% \mathrm{MS})$ \\
\hline Xeq & Equilibrium moisture content & (g water /g ms) \\
\hline $\mathrm{Xm}$ & GAB and BET monolayer moisture content & (g moisture/gms) \\
\hline Xo & Moisture content of the food material & (g water/g ms) \\
\hline $\mathrm{X}^{\mathrm{O}}$ & Frequency collision & $(\% \mathrm{MS})$ \\
\hline PFMo & Moringa oleifera leaf powder & $(-)$ \\
\hline $\mathrm{G}$ & Free energy & $\left(\mathrm{kJ} \mathrm{mol}^{-1}\right)$ \\
\hline$\Delta \mathrm{s}$ & Differential entropy & $\left(\mathrm{kJ} \mathrm{mol}^{-1} \mathrm{~K}^{-1}\right)$ \\
\hline
\end{tabular}

\section{Indices}

$\begin{array}{ll}\text { eq } & \text { Equilibrium } \\ \mathrm{S} & \text { system } \\ \mathrm{w} & \text { water } \\ \mathrm{V} & \text { vapour } \\ \mathrm{sat} & \text { state of saturation } \\ \mathrm{sp} & \text { anhydrous } \\ \mathrm{e} & \text { experimental } \\ \mathrm{m} & \text { model } \\ \mathrm{i} & \text { Row }\end{array}$

\section{References}

Aguirre-Ldredd RY; Rddriguez-Hernandez A.I; Velazquez G., 2017. Modelling the effect of temperature on the water sorption isotherms of chitosan films. Food Science and Technology, Vol. 37. No 1, pp. 112-118. 
Ahouannou C., Jannot Y., Sanya E., and Degan G., 2010. Experimental determination and modeling of desorption isotherms of tropical agricultural produce. Afrique Science. Vol.6. No.3, pp. 1-17.

Akoy E., Von Hörsten D., and Ismail M., 2013. Moisture adsorption characteristics of solar-dried mango slices. International Food Research Journal, Vol.20. No.2, pp. 883-890.

Arsalan N., and Torgrul H., 2006. The fitting of Various Models to Water Sorption Isotherms of Tea Stored in a Chaber Under Controlled Temperature and Humidity, Journal of Stored Products Research, Vol. 42, pp.112 -135.

Benhamou A., Kouhila M., Zeghmati B., and Benyoucef B., 2010. Modelization of sorption isotherms of the marjoram leaves. Review of Renewable Energies, Vol.13.No.2, pp. 233 - 247.

Benseddik A., Azzi A., and Allaf K.A., 2014. Modeling of desorption - isotherms of pumpkin for their drying $3^{\text {rd }}$, International Seminar on New and Renewable Energies, Ghardaïa - Alger October 13 and 14.

Boki K.., Ohno S., and Shinoda S., 1990. Moisture sorption characteristics of kudzu starch and sweet potato starch, Journal of Food Science, Vol.55. No.1, pp. 232-235.

Brunauer S., Emmett P.H., and Teller E., 1938. Adsorption of gases in multimolecular to bush-hammer, Newspaper of American Chemists Society, Vol.60, pp. 232-235.

Coronel A.Y., Ciro H.J., Restrepo D.A., 2016. Thermal and thermodynamic characterization of a dye powder from liquid turmeric extracts by spray drying. Revista Facultad Nacional Agronomía Vol. 69. Nㅜ1, pp. 7845-7854.

Erbas M., Ertugay M.F., Certel M., 2005. Moisture Adsorption Behaviour of Semonila and Farina, Journal of Food Engineering, Vol. 68, pp. 191-198.

Fasina O.O. 2006. Thermodynamic Properties of Sweetpotato', Journal of Food Engineering, Vol. 758, pp. 149 - 155,

Ferradji AA., cheheb H., Malek A., and Hadjad N., 2008. Isothermal of adsorption at $25{ }^{\circ} \mathrm{C}$ and $45{ }^{\circ} \mathrm{C}$ of apples charged with aqueous solutions and dried. Renewable Energies, Vol.11 .N 4, pp. 309 -319.

Giraldo G.C.E., Gloria I., Orrego-Alzate L.M., Grajales V.N., Telis A.L., Gabas J., and Telis R., 2011. Effect of drying methods on the thermodynamic properties of blackberry pulp powder efecto del método de secado en las propiedades termodinámicas de pulpa de mora en polvo Red de Revistas Científicas de América Latina: Sistema de Información Científica, Vol. 168. N ${ }^{\circ} 78$, pp.139-148.

Goudjinou C., Ahouannou C., and Soumanou M. M., 2016. Food and Therapeutic uses of Moringa oleifera and its SocioEconomic Significance in the South of Benin. International Journal of Green and Herbal Chemistry. Vol.5. N ${ }^{0} 2$, pp.110-121.

Goula A.M.G., Karapantsios T.D., Achilias D.S., and Adamopoulos, K.G., 2007. Water sorption isotherms and glass transition temperature of spray dried tomato pulp, Journal of Food Engineering, Vol.85, pp.73-83,

Henderson S.M., 1952. A Basic concept of equilibrium moisture. Agriculture Engineering, Vol.33, pp.29-32.

Iglesias H.A., chirife J., 1982. Water sorption parameters for food and food components, Handbook of food isotherms, Academics press, New York, 34p.

Iglesias H. A., and Chirife, J., 1976. On the local isotherm concept and mode of moisture bindings in food products. Journal of Agriculture and Food Chemistry, Vol.24, pp.1-77.

Kakou K.E., Akmel D.C., Abouo N.V., Assidjo N.E., Niamke L.S., 2015. Isothermal of adsorption of water of cocoa broad beans (theobroma cocoa L Merchant,). European Scientific Newspaper, Vol.1. ํ12, pp355 -370.

Kiranoudis, C.T., Maroulis, Z.B., Tsami, E. and Marinos-Kouris D., 1993. Equilibrium moisture content and heat of desorption of some vegetables, Journal of Food Engineering, Vol. 20, pp.55-74.

Koumoutsakos A., and Avramidis S., 1999. Enthalpy-Entropy Compensation in Water Sorption by Various Wood Species, European Journal of Wood and Wood Products Holz als Roh- und Werkstoff, Vol.57, pp.379 -382.

Krug R.R., Hunter W.G. and Grieger R.A., 1976. Enthalpy-entropy compensation.1- Some fundamental statistical problems associated with the analysis of van't Hoff and Arrhenius data. Journal Physical Chemistry, Vol.80, pp. 2335-2341.

Labuza T P., Kaane A., Chen JY., 1985. Effect of temperature one the moisture sorption isotherms and toilets activity shift of two dehydrated foods. Newspaper of Food Science, Vol.50, pp. 385-391.

Leffler JE., 1955. The Enthalpy-entropy relationship and its implications for organic chemistry. Organic Chemistry, Vol. 20, pp.1202-1231.

Madamba, P.S., Driscoll, R.H. and Buckle, K.A., 1996. Enthalpy-entropy compensation models for sorption and browning of garlic, Journal of Food Engineering, Vol.28, pp.109-119.

Mahmoud M. E., Amira M. F., Seleim S. M., and Mohamed A. K., 2017. Adsorption Isotherm Models, Kinetics Study, and Thermodynamic Parameters of Ni (II) and Zn (II) Removal from Water Using the LbL Technique. Journal Chemical Engineering. Vol. 62. $\mathrm{N}^{\circ}$ 2, pp. 839-850.

Medeiros M. L., Ayrosa A. M. I. B., Pitombo R. N. M., and Lannes S.C.S., 2006. Sorption isotherms of cocoa and cupuassu products, Journal of Food Engineering, Vol.73, pp. 402-406,

Muzaffar K.., and Kumar P., 2016. Moisture sorption isotherms and storage study of spray dried tamarind pulp powder. Powder Technology, Vol. 291, pp.322-327.

Ngono Mbarga M.C., Bup N.D., Mohagir A., Kapseu C., and Elambo Nkeng G., 2017. Moisture Sorption Isotherms and Properties of Sorbed Water of Neem (Azadirichta indica A. Juss) Kernels, Journal of Engineering Physics and Thermophysics. Vol. 90. $\mathrm{N}^{\circ} 1$, pp. 35-42 
Salgado MC., 1994. Modelling of water activity and enthalpy of water sorption in cassava chips, Drying Technology, vol.12, pp. $1743-1752$.

Shittu TA., Idowu-Adebayo F., Adedokun I.I., Alade O., 2015. Toilets vapor adsorption characteristics of starch endosperm powder and rheological behavior of its paste. Nigerian Food Newspaper, Vol.33, pp. 90-96.

Simo-Tagne, M., Romain R., Yann R., André Z., Béguidé B., 2016. Sorption behavior of four tropical woods using a dynamic vapor sorption standard analysis system. Maderas. Ciencia y tecnología Vol. 18. ํ3, pp. $403-412$.

Smith S.E. 947. The sorption of toilets vapour by high polymers. Journal of American chemical society, Vol. 69. ํㅜ 3 , pp. 646-651

Taoufik F., El Hadek M., Hnini M. C., Benchanaa M. B., El Hammioui M., and Hassani L. M. I., 2017. Sorption isotherms and isosteric heats of sorption of mint variety (Mentha viridis) leaves and stems: Experimental and mathematical investigations. The European Physical Journal Special Topics. Vol.226. N5, pp. 993-1000.

Timmermann E.O., 2003. Multilayer sorption parameters. BET or GAB values? Colloids and surfaces A: Physicochemical and Engineering Aspects, Vol.220, pp. 235-260.

Tsami, E., Maroulis, Z. B., Morunos-Kouris, D. and Saravacos, G. D.,1990. Heat of sorption of water in dried fruits, International journal of food science and technology, Vol.25.pp.350-359.

Wang N., and Brennan J.G.,1991. 'Moisture Sorption Isotherm Characteristics of Potatoes at Four Temperatures, Journal of Food Engineering, Vol.14, pp. 325 - 327,

Wolf W., Speiss W. E. L., Jung G., 1985. 'Standardization of Isotherm Measurements', In: D. Simatos and J.L. Multon (Eds.), 'Properties of Water in Food', Marins Nijhoff Publ. The Netherlands, pp. 661- 679.

Zhu W. K.., Wang Y., Chen L.Y., Wang Z.G.B., Wang L. B., 2016. Effect of two-stage dehydration on retention of characteristic flavor components of flue -cured tobacco in rotary dryer. Drying Technology An International Journal. Vol.34, N${ }^{\circ} 13$, pp.16211629.

\section{Biographical notes}

Codjo Goudjinou is an Holder of Mastery in Biochemistry and a DEA in Applied Biotechnology. PhD in Process Engineering and Food Science.

Dr. Ir. Clément Ahouannou is a lecturer at the CAMES. He is currently Teacher-researcher at Abomey-Calavi Polytechnic School / University of Abomey-Calavi where he carried out his research in the laboratory of Energetics and applied mechanics. He develops research themes such as characterization of agri-food products by drying and the influence of heat on product quality. This characterization approach is carried out in collaboration with the Research Unit for Enzymatic and Food Engineering at the Applied Chemistry Research Laboratory in the same academic institution. He defined parameterized models of drying kinetics and desorption isotherms for several agri-food products.

Dr. Gédéon Chaffa held a Diploma in Energy Conversion (ENSAM, Paris) and a Ph. D. in the Field of Energy Efficiency at the University of Abomey-Calavi. He is lecturer in the Department of Mechanical Engineering and Energy Studies of High Polytechnic School of Abomey-Calavi (EPAC) where he carries out research on Heat and Mass Transfer in the Laboratory of Applied Mechanics and Energetics (LEMA). He collaborates with the Research Unit for Enzymatic and Food in the field of parameterized model of drying kinetics and desorption isotherms for several agricultural products.

Dr. Ir. Mohamed M. Soumanou is a Full professor with the CAMS. Teacher-researcher, it is responsible for the Unit in Enzymatic and Food Engineering at the Applied Chemistry Research at the Laboratory of the Abomey-Calavi Polytechnic School/ University of Abomey-Calavi. Promoter of the Department of Food Technology Engineering, he develops research themes on the physicochemical and functional characterization of several agri-food products and fatty substances. It assesses the effect of water activity on storage stability and shelf-life by controlling various physicochemical properties, lipid oxidation rates, diffusion-law reactions, and enzymatic degradation low and intermediate moisture content in several food materials.

Received April 2017

Accepted June 2017

Final acceptance in revised form July 2017 